\title{
STRATEGY IN PROVIDING SERVICE TO THE COMMUNITY
}

\author{
Trio Saputra, Wasiah Sufi \\ trio_saputra@unilak.ac.id \\ Fakultas Ilmu Administrasi Universitas Lancang Kuning
}

\begin{abstract}
This research is expected to reach the service oriented library to the visitor. With the strategies undertaken to overcome the obstacles and shortcomings that occur. This research uses descriptive qualitative research methods and data collection techniques using observation, interviews, documentation. Informants in this research is the head and staff of UPT Library archive and documentation of Bukit Batu district Bengkalis District and visitors and community leaders in the library environment. In the data analysis used descriptive method that describes the Theory with the objective conditions and information on the results of interviews combined with the data of researchers in accordance with the results of field observation. Library Management at UPT Library Archives and Documentation District Bukit Batu Bengkalis Regency is not running optimally. Factors that become obstacles in providing services to visitors such as facilities and infrastructure that are not complete, the number and quality of human resources Librarian is not adequate.
\end{abstract}

Keywords: Strategy, Management, Education, and Service

\begin{abstract}
ABSTRAK
Penelitian ini diharapkan tercapainya pelayanan perpustakaan yang berorientasi kepada pengunjung. Dengan strategi-strategi yang dilakukan dapat mengatasi hambatan dan kekurangan yang terjadi. Penelitian ini menggunakan metode penelitian deskriptif kualitatif dan teknik pengumpulan data dengan menggunakan observasi, wawancara, dokumentasi. Informan dalam penelitian ini adalah adalah kepala dan pegawai UPT Badan perpustakaan arsip dan dokumentasi kecamatan Bukit Batu Kabupaten Bengkalis dan pengunjung serta tokoh masyarakat dilingkungan perpustakaan. Didalam Analisa data digunakan metode Deskriptif yaitu menggambarkan Teori dengan kondisi objektif serta informasi hasil wawancara digabungkan dengan data peneliti sesuai dengan hasil observasi dilapangan. Pengelolaan Perpustakaan pada UPT Perpustakaan Arsip dan Dokumentasi Kecamatan Bukit Batu Kabupaten Bengkalis tidak berjalan secara optimal. Faktor-faktor yang menjadi kendala dalam memberikan pelayanan kepada pengunjung diantaranya adalah sarana dan prasarana yang tidak lengkap, jumlah dan kualitas SDM Pustakawan yang belum memadai.
\end{abstract}

Kata Kunci :Strategi, Pengelolaan,Pendidikan, danPelayanan

\section{INTRODUCTION}

Opening 1945 law mandated that one of the objectives of independence is the intellectual life of the nation within the framework of national development, and supported by the practice of the ideology of Pancasila as the nation is essentially complete as his Indonesian human development. In the context of development, Indonesia has launched the development of a movement known as the national national. building development is ongoing activity and sustainable livelihoods of our people aim to improve both material and spiritual.
The concept of national development as outlined in the government's policies should reflect equitable development in efforts to achieve social welfare for every element of society towards a more meaningful or valuable, through the efforts of well-planned, sustainable, and dynamic for the progress and prosperity of the nation in accordance with the purpose state. for achieve these objectives, it is necessary the level of human resources through a program education. to this age of globalization, education is something very important, because education is the root of civilization of a nation. has been any improvement in 
the quality of human resources in order to respond to the opportunities and challenges for the advancement bangsa.Peningkatan life quality of human resources is an important part in achieving the objectives of the Unitary Republic of Indonesia, as stated in the preamble which the constitution of 1945, which is one the goal is educating the nation. For achieve these objectives the need for government policies to improve education, both formal and non-formal education.

Library serves as one of the factors that accelerate the transfer of knowledge, by karnanya library is a unity that can not be separated in the pendidikan.Selain system also, the library serves as a source of information, and is an important support means for a ilmiah.sebagai research reference materials or reference. It could be argued the existence of library support increased achievement and the quality of students, improvement and continuity of teaching and learning and quality enhancement Education. Characterized by the presence of the information society, the role, duties, and functions as well as the use of the library as an information center and educational institutions in the broad sense.

The development of information is one of the characteristics of modern life, and rational life. In the country - a country that already advanced. Library a mirror society progress, because it shows the library is part of everyday life needs. It was followed by the ease with access and completeness of facilities and the availability of adequate resources.

Given the times are so rapidly in the field of information and communication technologies, the library should try to follow and respond to the challenges of education are expected to be able to provide services and a different feel to the user Library. As public organizations that have a strategic role in educating the nation participated, libraries should capable of evolving with the development of cultural, social, and intelligence communities. From this role should libraries provide information services to the public service quality.

For it is certainly expected the existence of a strategy into the future direction and formation for the library in carrying out its functions and duties. Some strategies are designed UPT. Public Library, Archives and Documentation Bukit Batu subdistrict to improve library management and administration right effective among others: (1) Program Library.As a support unit, the Library is always working to improve the quality and quantity as well as developing the library into the library that is able to provide quick and precise information. The library is always seeking for improvement and enhancement of library services. (2) Setting a Library Card Making Policies These efforts are made to find out who those who visit the library and borrow books. For visitors who are not willing to make the library card is not willing to serve the library book lending. (3) Impose fines system. Library of fines for overdue books are returned and replace the damaged books. (4) To disseminate periodically. This effort to introduce the library to the general public and to visitors. While efforts were made to improve the quality of UPT services. Public Library, Archives and Documentation Bukit Batu subdistrict is as follows: (a) Increasing the resources in personnel and Honorary Promoting library (b) Conduct orientation libraries for new students Cooperation utilization of library collections to libraries other areas (c) education library users for users library. (d) for the library user education librarian staffs.

In this case the strategy shown is how the Optimal Library in an effort to provide services to the public, especially users of the library.

Agency Public Library, Archives and Documentation is a technical institute assignment area as supporting elements regents headed by a chief who is under and responsible to the Regent through the Local Secretary. 
In undertaking one of which is the development of the Library to meet the needs of the community, Bukit Batu sub district Government has established the Office of the Public Library and Regional Archives Bukit Batu subdistrict in 2004 based Bengkalis District Regulation No. 28 of 2001. In 2008 the Office of the Public Library and Regional Archives enhanced become UPT. Agency Public Library, Archives and Documentation Bukit Batu subdistrict Bengkalis Based on Regional Regulation (Perda) Bengkalis N0 10 of 2008 dated 28 September 2008 on the Organization and Work Inspectorate.

Basically UPT. Agency Public Library, Archives and Documentation Bukit Batu subdistrict simultaneously functions as an agent of change and an agent of culture which can be media and information sources for the wearer. To be able to provide good service constantly trying to improve itself into and out of the organization. Intended participate in developing education in Bukit Batu subdistrict have a positive impact on the increasing amount of interest in reading society.

According to the regulations Kabupatan Bengkalis Region No. 10 of 2008 on the organizational structure and Working Procedures UPT. Agency Public Library, Archives and Documentation, including the following: (1) The head, (2) Sub Administration (3) Section Archives, (4) Section services and resources. (5) Processing Acquisition Section.

Table 1. Data Number of Employees UPT. Agency Public Library, Archives and Documentation Bukit Batu subdistrict

\begin{tabular}{|l|l|l|}
\hline No. & Status of employees & Number of \\
\hline 1 & Civil Servant (PNS) & 3 \\
\hline 2 & Honorary & 4 \\
\hline \multicolumn{2}{|l|}{ Number } & 7 \\
\hline
\end{tabular}

Source: UPT. Of Library, Archives and documentation sub-district of the rock, 2016.

Judging from the number of personnel who runs a government agency in the field of informal education are very few in number, either civil servants or honorarium. whereas the institutions or organizations that run an organization of considerable scope that district. This resulted in less smoothness of services provided to pengunjung.Untuk determine the level of employee education in UPT. Public Library, Archives and Documentation Bukit Batu subdistrict Bengkalis in the following table:

Table 2. Identity Data Employee Education Unit. Agency Public Library, Archives and Documentation Bukit Batu subdistrict.

\begin{tabular}{|l|l|l|}
\hline No & Level of Education & Total \\
\hline 1 & Tier One & 1 Person \\
\hline 2 & High School or equivalent & 6 Person \\
\hline Number & 7 People \\
\hline
\end{tabular}

Source: UPT. Agency Public Library, Archives and Documentation Bukit Batu subdistrict, 2016.

The above table shows that the Education Level Employees in the Public Archives Unit, Archives and Documentation Bengkalis Bukit Batu subdistrict consists of various qualifications education. in terms of performing functions and tasks included determining its policymaking Library Human Resources is indispensable that has competence in the field. This should be considered in order to realize a reliable Librarian in working primarily provide services to visitors.

As for data on the number of books owned by UPT.Badan public libraries, archives and documentation of the rock hill sub-district from 2004 to 2015 can be seen in the table below.

Table 3: Data Collection Unit Books. Agency Public Library, Archives and Documentation Bukit Batu subdistrict of the Year 2004 to the Year 2016

\begin{tabular}{|l|l|l|}
\hline No. & \multicolumn{1}{|c|}{ TypeBook } & \multicolumn{1}{c|}{ Number } \\
\hline 1 & Fiction & 1759 \\
\hline 2 & Dictionary & 11 \\
\hline 3 & Lesson & 3,915 \\
\hline 4 & General & 3,097 \\
\hline \multicolumn{2}{|l|}{ Total } & 8782 \\
\hline
\end{tabular}


Source: UPT. Of Library, Archives and Documentation Bukit Batu subdistrict, 2016. Table 3 above, we can see that the number of books in the library is the most many kinds of textbooks, general books, and books fiksi.sedangkan types of books that at least is is the kind of book kamus.jenis fiction books from 2004 to 2015 amounted to 1,759 , then the type of dictionary book only amounted to only a total of 11 , then the type of textbooks totaled 3,097. thus can provide a clear picture of the number of books in the library is still very low and incomplete. To see the number of visitors who visit keperpustakaan we can see in the following table:

Table 4. Data Number of Visitors on the UPT. Agency Public Library, Archives and Documentation Bukit Batu subdistrict from 2010 to 2016.

\begin{tabular}{|l|l|l|}
\hline No & Year & Number of Visitors \\
\hline 1 & 2010 & 5660 \\
\hline 2 & 2011 & 6770 \\
\hline 3 & 2012 & 5697 \\
\hline 4 & 2013 & 5198 \\
\hline 5 & 2014 & 5115 \\
\hline 6 & 2015 & 4189 \\
\hline \multicolumn{2}{|l|}{ Total } & 32629 \\
\hline
\end{tabular}

Source: Processed Data Unit Public Library Board, Archives and Documentation Bukit Batu subdistrict Year 2016.

Judging from the data on the number of visitors more tends to decrease, whereas Unit, Public Library, Archives and Documentation Bukit Batu subdistrict've attempted to make to the quality of service. As for the issue of pre-survey baberapa that researchers do with some visitors found some problems in UPT. Agency Public Library, Archives and Documentation Bukit Batu subdistrict, namely: (1) The lack of computer facilities, thereby reducing the quality of service. All kinds of purposes related to reporting handwritten and typed elsewhere, not in the library. (2) Employee Skills Archival field is still low, and less orderly neat layout books. (3) Many borrowers who do not return the borrowed book led to the book collection is reduced and visitors feel disappointed because the book when looking for is not available. (4) The lack of the number of officers in charge of providing services causing berkualitasnya not care. (5) The function of socialization of the public library that did not go well, so the Library is not effective in its function.

Based on the phenomenon of the problem above we can know how the need for a strategy for UPT. Public Library, Archives and Documentation Bukit Batu subdistrict in enhancing the role of the library sabagai an educational institution to the community around the District of Bukit Batu

\section{REVIEW THEORETICAL}

According to GR Terry (1997: 15) in Harbani Pasalong in the book Theory of Public Administration Management is a process or framework, yangmelibatkan guidance or direction of a group of people towards organizational goals or intentions nyata.manajemen also is sutau science and art. Management as human collectivity, can be defined as a collection of people who work together to achieve a common goal.

\section{Public Services Strategy Management Structure}

Based on evolving history, then Nawawi mentions "Management strategies in government circles as a new paradigm, which has been applied to almost all organizations. There are two things that can be used in distinguishing the implementation of strategy management in profit and non-profit organizations, namely the profit organizations value-orientedand non-profit organizations aregoal-nlai.Value underlying profit organization (company) is falasafah which contains the values of competition free between similar business organizations, through all sources owned empoerment to achieve strategic objectives. Purpose (for-profit) is to maintain and develop the existing for a long time, through the ability to profitkompetitif ongoing basis.being a nonprofit organization constituted by philosophy devotion dam values of humanity. The goal is to achieve mutual prosperity in general community. 
Service is the provision of government services, the private sector on behalf of the government, the private sector on behalf of the government or the private sector to the public with or without payment in order to meet the needs or interests of the community.

While other types of public services according to the State administrative agencies are: (1) Government Services is the type of community service related with common tasks of government, such as service ID card, driving license, tax, licensing and immigration. (2) The service development is a kind of community service related to the provision of facilities and infrastructure to provide facilities to the people in their activities as citizens. Services include the provision of roads, bridges, ports - ports, and more. (3) Service utility is a kind of service related to public utilities such as electricity, water, telephone, local transportation. (4) Service of clothing, food and shelter are the kind of services that provide the basic needs of society and the needs of housing, such as the provision of rice, sugar, oil, gas, textiles and cheap housing. (5) Service community is the kind of service that is viewed from nature and its importance is more emphasis on the activities of social, health care, education, employment, prisons, homes Based on the above, it can be concluded that the library service is included in the service of social emphasized in social activities: education.

Library services is the process of helping users (pupils, students, teachers and the general public). in taking educational programs, self-study, broaden their knowledge and improve intelligence, skill, where the high quality of education is a bit much, depends on the full library as an information center.

\section{Apparatus of Public Service}

A government agency can not be separated from the apparatus as the executor of governance, this is in accordance with the opinion of hadayaningrat soerwono saying that: the apparatus is the administrative aspects required in penyenggaraan government or the state, as a means to an end-aspect organization. Apects administration was mainly exist in the institutional or organizational and staffing. Apparatus according to the above definition to say that the apparatus is a staffing organization in the organization of the administration or state in serving the community. Aspects of an institutional or organizational administration in governance. Moenir in his book diIndonesia management of publicservices,said that the government in providing the best service to the public can be done in different ways. (1) ease in handling interest (2) get a reasonably services. (3) receive the same treatment without favoritism. (4) receive treatment honest and forthright.

Apparatus of public services is meant here is the employees of the library or in other words puatakawan. The librarian is an important pillar in the orientation of the library in providing knowledge and education services to library patrons.

According to (Sugiarto, 1999: 217), in Mifta Thoha in the world of librarians can we application various prima.yaitu service concept can be personalized prima such as: Friendly, Courtesy, Confident, Neat, Ceria and Easy going.

By knowing the personal concept above, undoubtedly personal librarian will receive the degree of appreciation of the public library users well and got a positive response so that they are motivated to visit keperpustakaan, with such services we provide can be realized on the creation of optimum service and the purpose of excellent service excellence has set.

\section{Study On Organizational Strategy Concept}

Strategy is the means used to achieve the ultimate goal (target). The overall strategy: the strategy covers all important aspects of the company or the organisasi.srtategi integrated: all part of the 
plan mismatched or another and Corresponding. According to Coulter in Kuncoro (2005: 12) strategy is the number of decisions and actions aimed at achieving goal the (goal) and adjust the organization's resources with the opportunities and challenges facing the industry environment.

The term strategy comes from the Greek strategos means general but in the ancient Greek language often means officers of State (state officer) with a function that wide. Strategy is an art of using the skills and resources of an organization for the most favorable conditions. (Salusu, 2004: in Rangkuti (2006: 4) The strategy is a response to continuous and adaptive to opportunities and external threats and internal strengths and weaknesses that can affect the organization. Barry (2005: 17) in the Tejo Tripomo and Udan stated that the strategy is plan what you want to achieve or about to become what an organization of the future (direction) and the like where how to achieve the desired state of the (s). According to Tripomo (2005: 17) there are several definitions of strategy, namely: (a) strategy is kerangaka or plans that integrate the goals (goal),policies (policy) and actions / programs of theorganization.(A stetegi is a pattern or plan that integrates an organization of major goals, policies and action into an cohesivewhole).(b) strategy is a plan about what you want to achieve or what an organization wants to become in the future and how to achieve the desired state.

By this definition download strategy formulation sequence had become a fundamental framework where an organization will be able to declare a vital continuity while at the same time he will have the power to adapt to the environment are always changed. general strategy is the art of using the skills and resources of an organization to achieve goals through effective relationships with less environmental conditions that are most important profitable.Strategy important it is understood by every executive, manager, head or chairman, directors, senior and junior officers, officials of high, medium and low. It must be lived as a strategy implemented by every person at every level instead only Allowed high officials.

Hatten and Hatten in Purwanto (2008: 76) gives some hints on how to manufacture so that the strategy can succeed, including: (1) The strategy must concistent with environment. follow currents moving developments in society (not to be against the current) in an environment that provides opportunities to move forward. (2) Each strategy not only makes one strategy. depends on the scope of Activities. If many strategies that made the strategy one must be consistent with other strategies. (3) An effective strategy should focus and unify all resources and not pull apart from one another. (4) The strategy should satisfying attention on what is a strength and not on points precisely to the weakness. in addition, should also benefit the weakness of competition and create the appropriate steps to occupy a stronger competitive position. (5) Resources is a strategy that kritis.mengingat is an exciting possibility, then it should make something decent and workable. (6) The strategy should account for the right risk is not too great. indeed every strategy has risks, but must be careful so as not to plunge the organization into the hole that besar.oleh Therefore, the strategy should be controlled. (7) The strategy should be prepared on a foundation of success that achived strategize on failure. (8) The signs of the success of the strategy revealed with the support of relevant parties, especially the executive, of all leaders and units within the organization.

Furthermore, according to Lina and flax (2008: 9-56) there are three strategies in the management of operating strategies, namely:

1. technology strategy

Things to consider in the planning process is to establish the technology with innovative technology strategies. According balla 1987 (lina and lena 2008: 9) technology rooted in two things: 
a. Technology push (impulse technology) that innovation is the result of basic research. This model is not oriented to the needs of existing communities and urged, creates the same requirement.

b. Market pull (pull out of the market) is a technological innovation that arises because the socio-economic needs using basic and applied research to create products that can to meet those needs.

2. innovation strategy

Innovationrefers to the renewal of a product, processes and new services, there are several important aspects of the innovation strategy formulation to be studied thoroughly by the organization include:

a. Managerial Competence

Product innovation will be successful if it is planned and implemented with the baik.Perencanaan includes research, development , engineering, manufacturing, and basic introduction.

b. Commitment to leadership and active participation of subordinates. Success demands innovation company leadership commitment and active participation of society. Leaders should be open so that subordinates can be more active, which in turn will drive the success of the internalization of a culture of innovation within the company.

c. Mastery of $\mathrm{R} \& \mathrm{D}$ (research and development) and technology $\mathrm{R} \& \mathrm{D}$ is a division within a company in charge of and responsible for the conduct of research tasks (develop innovations) in order to develop the company. Mastery of R \& D (research and development) and technological innovation of the product development process to the demands.

d. Faslitas R \& D

To make the strategy of innovation, continuous improvement must be supported by proprietary R \& D facilities are adequate. e. Network Information System initial steps to be taken by the company's organization in innovation is well aware that consumers who adressed for necessary information system capable of identifying precisely the various needs of enterprises and consumers.

f. Innovation Timing

The timing to enter the market is one of the main reasons for the success or failure of the product.

From some of the above study authors to conclude that the strategy is a long-term goal of an organization and to achieve that goal required ways of operating so-called tactics that have relevance to each implementation strategy is also applied to public sector organizations that put more emphasis on functionality namely government services, development and empowerment by the bureaucracy. As for the approach using the strategic management approach. This is because the strategy management process thorough strategy so that the desired objectives can be planned, implemented and controlled properly.

\section{Study On Theory}

Librariescan be interpreted simply as a repository for books which can then be read and borrowed to visitor. According to Basuki (1994:26) library is a library service. ingredients should at any time be available to those in need, no library if there is no service.Library make sense as a collection of books and non-books are managed and maintained, and loaned to the community to be used according to kebutuhan.basuki revealed, there are some important buildings Library meaning, ie.

1. The library is a building science and information as an educational medium.

2. As a source of information such as studies, research, technology, and cultural preservation.

3. Comforted by reading the amount of information such as books, magazines, newspapers, and movies.

4. Educating the nation as a visitor national development. 
More Sutarno NS (2005:132) states that there are eight dimension values of the library, namely:

1. educational value

Libraries have educational value and instructive for many members of the public. With the availability of information sources from various disciplines such as books, magazines, newspapers, and other sesabainya will improve the insight, knowledge, and directly or indirectly will improve education.

\section{2. information value}

Eachis one of the central library in the library informasi.Informasi course selected, dihimpin, processed, prepared, packaged well, so that all information contained in the library really have studied and analyzed and considered its usefulness.

\section{Economic Value}

Given the high cost of books and other information sources, existence of libraries also bring economic value to the community or visitors, because in view of the library's books and other information sources do not need to be purchased, but was loaned to a specific period.

4. Value History and Documentation entire collection of books and information available in the library is the result of creativity, and man's work in the past until the present ini.Semua it contains the meaning of history and documentation for human development.

\section{Social value}

is fundamentally a library has a social value. Social value is growing because the library is not intended to become an institution that is commercial for profit but based on the benefit of society, especially the economically weak who can not afford to buy books.

6. Cultural Values

library is a cultural agent, change and development. Because of all the discoveries the past that there are not only stored in the library, but studied and researched, and used as a basis for the development of science.

7. Values of democracy and fairness
Library has the value of democracy and justice that does not discriminate discriminate but all have been specified in the rules of conduct appropriate policies and focus on service and each user's library services are given the freedom to use sources of information for the development of science and education.

8. Rated entertainment / recreation

In principle, everyone is in need of entertainment and recreation. the presence of the library is expected to answer all of it by bringing a different feel for pleasure, serenity, satisfaction of the visitors.

The views above explained that the library has a complex meaning primarily for the satisfaction and needs of the visitors / the public, especially in order to increase interest in reading society. effort increasing interest in reading must be backed-quality books that the library has a higher quality of measured baik.mutu library ability to provide the right book to your visitors when the book was searched and quality desired. if the officer can provide appropriate services, accurate and true to the visitor and regulated in ways that services system, so as to provide excellent service to visitors. According Sutarno NS (2005: 113) says that the administration and the organizers of the library service should meet the wishes of the user / visitor center, which is in in this regard:

a. Provision of information according to the user wishes

b. Time, unimpeded, adequate and not overly restrictive

c. Freedom, ordinances, and access to information, not stiff with supervision loose, not too tight, orderly, conducive, and sympathetic

d. atmosphere is fun, safe, calm, far from noise

e. Attitudes and behavior of officers were attentive, friendly, polite, nature guide, guiding, attentive, and covered the issues

f. the rules are simple, easily understood and followed and implemented 
g. existence of facilities and services that others, such as directions, details, short, or else

h. Creates a good impression, fun, satisfying, so people come back again Library

i. oriented to customers / visitors and be independent.

Library information services in the broadest sense, is how to reach the whole community, the library closer to visitors and distribute information in the form of interaction between service providers officers / employees and service users / visitors, the transfer of knowledge from the source to the user.

Regarding the activities of librarianship, ideally need for the Training Center for librarians so as to establish a certification for certain competency standards for librarians Indonesia to competitiveness tinggi.adapun the duties of one's librarians are as follows:

1. To provide appropriate services to the visitor according to his ability.

2. Understanding the use of reference collections such as dictionaries, encyclopedias, maps and so forth.

3. Understand the principle - the principle of cataloging, teaching, classification, information retrieval.

4. Understanding the use of literature, bibiliografi, indexes, and so forth.

Blasius Sudarsono (2004:

states, what was once called the library turns into information. This service is due to changes in forms of media that are used today not only book. result changes in how to manage the whole process of creation, encoding, storage and reuse of documents in all its forms, because in addition to changes in media technology and management, there has been a previous change include the number of people, the establishment of new classes in society, the rapid development in education, and the provision of other forms of new services for members of the public.
To answer it all, libraries are required to carry out the strategy by carrying out promotion and poromosi first service. Steps services in the sale usually begins by building up the library's self-image dahulu.selanjutnya librarians and library managers must have the courage to show something new in the sense of daring to make a breakthrough new with a new paradigm that can change people's perception of libraries Identics with information.

as a waitress as the information becomes pustawan transponder (change agents) and providers (taking action) information. stages next to the user based service and superior services that follow the development of the necessary effort needs thus users. with partnership (cooperation) with various perpustakaa both within and negrihal outside of the above shows the rapid flow of new information needs pula.apabila librarian persisted wear traditional forms of library services to the needs of today, there will be gap. reject of the expert opinion, so this time librarians should provide excellent service, namely an attitude or way of librarians in serving the consumer with the principle of user-based services and superior service that aims to satisfy users, increase user loyalty, increase sales of products and services right in increasing the number of users.

Based on the concept of improving the quality of library and information services, as well as the opportunities, challenges and internal factors and external support increased competitiveness, it can generally be taken as the policy measures relating teh first externally policy. on internal measures there are three things that need to be done, namely: organizational restructuring, improving the quality of human resources (HR), and the management arrangement.

At this time the mechanism of action with the existing organizational structure tends stratified (lengthy bureaucratic), the 
increasing dependency on the leaders of the unit is very large, so it is difficult to obtain creativity and inovasi.Oleh therefore need to restructure the organization, duties and functions and mechanisms of action facilitate libraries / librarians need to be set firmly and clearly, so that librarians / libraries have more authority in determining the wisdom lax in their duties and are expected to foster creativity.

The second activity involves enhancement ability of librarians. by Nurhadi (1999: 18), the librarian of the cutting edge library services. and no less importance in completing the library facilities and infrastructure that is reliable computer Provision (computers, internet) so that users can sum up the information needed to quickly, accurately and current besides internal policies need to also think about the external policy or rather a policy in outside. minimal associated with two principal parties to note is regarding the development of science and technology and efforts curious library products.

To keep pace with the rapid development of science and technology so that produce large amounts of technical and scientific information, it needs to establish a network of information, both with the library department environment within the country and overseas, so that information can be presented quickly and accurate concerning the marketing of products to keep in mind that marketing is an approach Any planned benefit both sides, both the library and the community users for optimal market information services, libraries and librarians need to observe and pay attention to potential user groups. in marketing activities, librarians should be able to communicate all kinds of services available to users and attract them to stay use it for support the successful marketing of library services, there are some elements that need to be considered, among other things:

1. That the results of the activities offered have value services specific to the user so they are willing to pay a price set.
2. That information needs to be processed in a professional manner so as to facilitate the retrieval so that users can find them at any time as needed.

3. That librarians are elements of strength in the marketing of library services.

\section{Theory Concepts Documentation and} Archives

Documentation is a part of the activity or event that made olehsuatu organization or government agency. documentation is also a collection of records work, either in the form of images, text figures, as well as data. Documentation is something written, printed or recorded to be used as evidence or keterangan.sedangkan in managing the documentation as a material for a learning function reflection of activities as a tool evaluation from planning to the implementation of a learning model. in terms of the kind of documentation there are several kinds of learning:

1. visual documentation, in the form of captured important events such as a camera. The result is images of the sequence of events during the activity.

2. Audio documentation, this kind of emphasis on sound recordings in the room during the activity.

3. Documentation is a business process (in this case the business is not traded, but rather a process in the implementation of the management.

The documentation is a thing which must first be determined and resolved by a instansi.Seperti status reports, and schedules are also important.

\section{Understanding Archive}

Informationis an important thing in something organizations, both government organizations and private sources. Information can be defined sabagai one very important part to support the work processes of administration and implementation of the management functions of the bureaucracy in the face of changing circumstances is expanding rapidly. 
Meanwhile, according to addolf brennek, 1953. Archive defined as papers and documents that arise from the operations of an agency trade legal.atau as Suber and evidence of the past.

Eugenio Casanova, 1867, defined as the addition of an orderly archive documents - documents that were created during the ole activities $h$ of an institution or individual.

\section{Studies on}

Managementis a process or framework, involving guidance or direction of a group of people towards organizational goals or intentions real. management also is a science and art.Management art, is defined as the science of planning, organization, preparation, briefing and supervision to achieve the set goals

Management as a human collectivity, can be defined as a collection of people who work together to achieve a common goal.

\section{Public Services Strategy Management Structure}

Based on the historical development, then Nawawi mentions "Management strategies in government circles as a new paradigm, which has been applied to almost all organisasi.Ada two things that can be used in distinguishing the implementation of strategy management in profit and nonprofit organizations, namely the profit organizations value-orientedand non-profit organizations aregoal-nlaithe value of the underlying organisasiprofit (company) is falasafah which contains the values of free competition between similar business organizations, through all sources owned empowerment to achieve strategic objectives.

\section{Study On Organizational Strategy Concept}

Strategy is the means used to achieve the ultimate goal. The overall strategy: the strategy covers all important aspects of the company or the organisasi.srtategi integrated: all part of the plan mismatched or another and bersesuain.Menurut Coulter in Kuncoro (2005: 12) strategy is the number of decisions and actions aimed at achieving goal the(goal) and adjust the organization's resources with the opportunities and challenges facing the industry environment.

\section{Study On Theory}

Librariescan be interpreted simply as a repository for books which can then be read and borrowed to pengunjung.Menurut Basuki (1994:26) library is a library service. ingredient should at any time be available to those in need, no library if there is no service. Library make sense as a collection of books and non-books are managed and maintained, and loaned to the community to be used as needed.

Theory Concepts Documentation and Archives

Documentation is a part of the activity or event that made by a goverment.documentation organization or institution is also a collection of records work, either in the form of images, text figures, as well as data. Documentation is something written, printed or recorded to be used as evidence or decription in managing the documentation as a material for a learning function Reflection activities as a tool evaluation from planning to the implementation of a learning model.

\section{METHODS}

This study was conducted in UPT. Agency Public Library, Archives and Documentation Bukit Batu subdistrict Bengkalis. The authors of this study used qualitative methods, where the authors obtained information from informants considered capable of providing answers and true and accurate information objectively. To obtain accurate data, the data collection techniques used as follows: (a) That Interview data acquisition techniques that are used to earn information directly, in-depth, unstructured and individually. semi-structured interview is the interview used in qualitative research where the interviewer can freely provide 
questions from various aspects and directions to get a complete and in-depth information. (b) The collection of data through observation run to see and observe directly the event or events through pristiwa or incident through a systematic manner. Direct observation of the observed consist of the administration given to visitors. (c) Documentation Here researchers helped attach some research data supporting documentation. Among displaying condition such as a photo library building library, photo Administrative completeness and form of service to library patrons. The data analysis used descriptive method that describes the theory with the objective conditions encountered in the field are analyzed with data triangulation technique, which is information combined with interviews and data that can be combined with the opinions of researchers in accordance with the results of field observations. this is done by steps and stages certain.step by step it is necessary to collect data, and then analyzed using a qualitative approach in the form of questions the answers of informants research, having analyzed drawn the conclusion that the end result of the study.

\section{RESULTS AND DISCUSSION}

\section{The phenomenon of existenceLibrary}

Libraryis a gathering place and information collection either in the form of printed, audio, visual or electronic form that can be utilized by the public. Library serves as one of the factors that accelerate the transfer of knowledge, by karnanya library is an integral and inseparable in the education system of an institution. In addition, the library serves as a source of information, and is an important support means for a scientific research as a reference tool.

See the functions of the library such that it is worth note by the librarian or the library that the library should be able to keep pace with developments in science, technology, culture and other aspects, by karnanya impression of the library as an ancient institution must be dismantled, including also issues the library service should initiate user-oriented services. In this study, the authors have made observations to UPT. Arsi Library and Documentation Bukit Batu subdistrict gives importance to the role of public education institutions in Bukit Batu. It is characterized by some of those visitors who are reading and searching books in the Library. To find out about the condition of the visitor, the authors conducted interviews with Ka. UPT. Public Library Archives and Documentation Bukit Batu subdistrict. With the following explanation:

"These visitors mostly during Library dominated by elementary school students and high school who happened to elementary and high school are close to the UPT environment. District Library also sometimes included the teachers ".(Interviewwith the head of Archives and Documentation UPT.Perpustakaan Bukit Batu subdistrict, 2016).

From the description above, the interview can be seen that because the location of the school environment Library Library user is more widely used by students, whether they are looking for information or visit only.

As a government agency in the world of education, Library Bukit Batu subdistrict of course expected to provide optimal service to visitors. Regarding Operational hours Library authors get an interview, with the following caption:

"Archives and Documentation Library Unit Bukit Batu subdistrict Library services open from 08.00 until $16.00 \mathrm{pm}$ on Monday to Saturday. However, at 12.00 for administrative services as well as borrowing and repayment services closed for lunch, then reopened at 13:30 ". (Interview with KA. Administration of Archives and Documentation Library Bukit Batu subdistrict, 2016).

From the description above interviews we know that the operating hours of the library is open every day except holidays. This course provides the 
opportunity for visitors to enjoy the library information serv opened almost every day, then, of a system of services provided, the author tried to interview some of those visitors who happened to be in the library when researchers conducted observations. When the interview is done, visitors to register registration became a member of the Library. The authors also find on the observation that the administration services provided UPT. General Pespustakaan Agency, Archives and Documentation Bukit Batu subdistrict still far from expected. This is due to the facilities and infrastructure to provide the service is still using a typewriter and not using the computer, either in making even a library card in the manufacture of a letter to the direntalkan still typing.

For more details, the authors conducted interviews with some of the visitors to the ease in handling the UPT Administration. Agency Public Library, Archives and Documentation Bukit Batu subdistrict Based on interviews conducted by the author, can be obtained as follows:

"in addition to the lack of the number of officers, accuracy officer in putting the book in place, we also feel concerned about the library district level to create cards libraries still use typewriters and computers in the library yet, so terkendalanya fluency in administrative services such as creating a library card

and correspondence."(Interview with library visitors in 2016).

From the interview can be concluded that the administrative proceedings due to lack of good infrastructure is inadequate in UPT. Agency Public Library, Archives and Documentation Bukit Batu subdistrict, so that administrative proceedings be slower and less effective.

Furthermore, during the author conducted observations, the Library Unit level this district very quiet visitors. Visitors range from only 5 or 6 people who visit on one day. To answer these phenomena, the authors interviewed one of the library staff, the following explanation:

"In recent years we recognize that this is indeed diminishing Library visitors, it also affects the spirit of employees who can not be effective in their role. Including from returning books also do not exactly on the deadline for repayment by library users. (Interview with Staff Archives and Documentation Library Service District of Bukit Batu. 2016).

Description of one of the above informant explained that the decrease in the number of visitors who come library, also includes provisions that do not return the book timely.

A review for us that the library is a public organization that has a strategic role in making national life. The development of the library reflects the social, cultural and educational society, so that the library development is inseparable from the development of society itself. This means, that development library will be affected by the development of the needs and desires of pemustakanya, so the library must seek the fulfillment of the desires and needs of the pemustaka.

A phenomenon that occurs when the library district level area less attractive to users / pemustaka this case needs to be examined why. By utilizing at least pemustaka collection / information available in the library, it is necessary in the evaluation of the cause. Absence of them in the library because of the ignorance of the pemustaka that the library was actually available information they are looking for but they do not know, or absence of the library is because officers were not friendly or because of lack of personnel so as to ask something had to wait quite a long time. To find the balance between the services needed by the visitors at the Library and Documentation Bukit Batu subdistrict, I get the following information:

"activities of library services provided to visitors who come to the library 
in the form of lending services / returning books, The service of a membership card, also make arrangements and numbering thebook."(Interview with Staff Archives and Documentation Library Service Bukit Batu subdistrict, 2016).

From the information submitted, can we know that the library service is still watching. This indicates that the library has not been able to perform its role as an information service that is real. The services provided merely on the scope of borrowing and return books.

Furthermore, the Library book collection that continues to decrease, we can see the description of recapitulation report data on borrowing and returning books in January s / d in December 2015 of the following:

Table 5. Summary of the report borrowing books in UPT. Public Library, Archives and Documentation sub-district of Bukit Batu in January s / d December 2015

\begin{tabular}{|c|c|c|c|c|c|c|c|c|}
\hline \multirow[b]{2}{*}{ No } & \multirow[b]{2}{*}{ Month } & \multicolumn{6}{|l|}{ Borrowing } & \multirow[b]{2}{*}{ Total } \\
\hline & & Kindergarten & elementary & $\begin{array}{ll}\text { junior } & \text { high } \\
\text { school } & \\
\end{array}$ & Senior & STUDENTS & GENERAL & \\
\hline 1 & January & - & 24 & 9 & 23 & - & 16 & 72 \\
\hline 2 & February & - & 28 & 7 & 15 & - & 14 & 64 \\
\hline 3 & March & - & 34 & 11 & 6 & 7 & 16 & 74 \\
\hline 4 & April & - & 40 & 5 & 10 & 3 & 18 & 76 \\
\hline 5 & in May & - & 39 & 16 & 5 & 2 & 17 & 79 \\
\hline 6 & July & - & 35 & 22 & 10 & 6 & 15 & 88 \\
\hline 7 & July & - & 29 & 25 & 36 & - & 11 & 101 \\
\hline 8 & August & - & 34 & 23 & 44 & - & - & 101 \\
\hline 9 & September & - & 24 & 29 & 27 & 8 & 10 & 98 \\
\hline 10 & October & - & 21 & 29 & 19 & 9 & 6 & 84 \\
\hline 11 & Nov & - & 17 & 49 & 31 & 6 & 2 & 115 \\
\hline 12 & Dec & - & 13 & 20 & 18 & - & 2 & 53 \\
\hline \multicolumn{2}{|c|}{ Total } & - & 384 & 384 & 245 & 244 & 41 & 127 \\
\hline
\end{tabular}

Source: Data report Year-End Unit, Agency Public Library, Archives and Documentation Bukit Batu subdistrict, 2015.

Table 6. Summary of the report for book returns UPT Public Library, Archives and Documentation Kec.Bukit Stone in January s / d December 2015.

\begin{tabular}{|c|c|c|c|c|c|c|c|c|}
\hline \multirow{2}{*}{ No } & \multirow{2}{*}{ Month } & \multicolumn{6}{|l|}{ Returns } & \multirow{2}{*}{ Number } \\
\hline & & kindergarten & elementary & junior high school & senior & STUDENTS & GENERAL & \\
\hline 1 & January & - & 24 & 9 & 23 & - & 16 & 72 \\
\hline 2 & February & - & 28 & 6 & 15 & - & 14 & 63 \\
\hline 3 & March & - & 34 & 11 & 6 & 7 & 16 & 74 \\
\hline 4 & April & - & 29 & 5 & 10 & 3 & 18 & 65 \\
\hline 5 & in May & - & 20 & 16 & 3 & 11 & 3 & 49 \\
\hline 6 & July & - & 34 & 21 & 8 & 4 & 5 & 72 \\
\hline 7 & July & - & 25 & 21 & 20 & - & 15 & 81 \\
\hline 8 & August & - & 28 & 23 & 40 & - & - & 91 \\
\hline 9 & September & - & 20 & 26 & 21 & 4 & 5 & 76 \\
\hline 10 & October & - & 21 & 27 & 21 & 10 & 6 & 85 \\
\hline 11 & Nov & - & 24 & 39 & 23 & 6 & 2 & 94 \\
\hline 12 & Dec & - & 11 & 19 & 13 & - & 2 & 45 \\
\hline \multicolumn{2}{|c|}{ Total } & - & 298 & 298 & 219 & 244 & 41 & 102 \\
\hline
\end{tabular}


Source: Data Unit Year End report. Agency Public Library, Archives and Documentation Bukit Batu subdistrict, 2015.

Based on the comparison between Table 5 to Table 6, it is known that there is no similarity or balance between the number of books loaned the book is returned, it would impact on the number of books are reduced so megakibatkan books are sought by many visitors who do not exist.

Under these conditions, the authors conducted interviews with the board of UPT. Library Board Umu, Archives and Documentation of the Regional District of Bukit Batu in order to seek out clarity on these issues, based on interviews conducted by the author, can be obtained the following explanation:

"One of the barriers of our employees in managing the library is still the number of borrowers book that does not return a book to the library in accordance with a predetermined time. As a result, the more the number of books available in the library collection continues to decrease. One reason is the lack of awareness of the borrower book to return the book in accordance with the time, when it should be the books loaned to others, so that the library does not need to add to the collection at anytime."(Interview with the Services Section and the Reference Unit, Agency for Public Library, Arsp and the Regional District of Mount Batu.2016 Documentation).

Based on the results of interviews conducted by the author with the management of UPT. Agency Public Library, Archives and Documentation District of Bukit Batu The can be concluded that the lack of awareness of borrowers to return books books library be the main cause that led to the existing books in the library continues to decrease.

Furthermore, the attitude and actions made by librarians in providing services would be so will affect the interest of visitors to the library. visitors to the library is a service from the service object information and knowledge from a government agency that is also responsible for making the community as a society that is informative and rich in knowledge. Basically, people want to get information:

1. fast means that the information can be obtained without the need for a long time.

2. convenient means of information is not difficult to obtain.

3. accurate in the sense that the information obtained can be responsible for the truth.

4. The cost means that the information obtained does not cost that much to get it,global

5. that the information obtained is a common and recognized information public and specific

6. that the information obtained is something special.

Regarding the treatment given by the officer to visitors writer felt directly upon the observation that treatment is given is to be serving not asked to be served, such as telling visitors to sign the guest book before using the material library, ask the benefit of visitors, if you want to put library materials officer immediately showed him the place and if you want to restore and borrow a book, then immediately enthusiastic tells visitors to get to the return of books and others. But because the limited number of employees a little concern on the visitor employee treatment can not completely, as if visitors do not find a specific book then the officer just ordered to look for it carefully, because if the clerk to help you find the book then there will be a section that no officers. Seeing the condition of the number of personnel librarian bit, plus the educational status of employees who are not yet sufficient, this being an issue of urgent matters in the ministry. This could definitely be a highlight for visitors to the ability of librarians satisfaction in performing their duties. Thus it can be concluded that the 
treatment given to the visitor needs to be improved in order to better and could add employees with education and training for employees who continuously to the smooth running of services provided to visitors.

\section{Library management}

Realized together that technological advances have brought major changes in the governance of human life which includes working procedures, procedures for communication education and various forms of public service. Library as an institution of public services that perform various activities by referring to the services nonprofit or non-profit-making would not be able to develop themselves in the competitive world of information by because the library must transform itself into an institution that is more attractive, competitive by creating a variety of services in the form of commodities that makes visitors want to come library.

In this case, we need a strategy in an effort to realize the optimal library services in providing information and knowledge to people. The strategy is a long-term goal of an organization and to achieve that goal required operational methods called tktik are independent from each other woods.

Strategies referred to in this research is the management of Bukit Batu District Library fore in running role as an educational institution for the community environment of Bukit Batu subdistrict. By because that's necessary to do some relevant actions and provide a clear substance in terms of the development of library services.

In achieving this goal, the author tries to apply the theory developed by lena and lina in management operations strategies with the objective phenomena research. In this theory systematically explained that in an agency or company for future actions required three operational processing to be a tactic to achieve goals. The strategy is an ongoing process systematically from risky decision making by utilizing as much as possible anticipatory knowledge and systematically organize its efforts to implement the decision to follow the results as feedback for continuous development.

The exact reasons for wanting a strategy in the development of this library is to meet the challenges facing libraries in the role that influence the development of today's information technology. Information, knowledge, education can now be obtained from a variety of things, especially with the sophistication of information technology. As one example, students as well as students prefer to look for the lesson and scientific resources of the Internet compared with keperpustakaan visit. The habit of reading the book was turned into a fun adventure to find information about the virtual world. On one hand, this is a positive thing for the work of The intelligent human in the birth of the development of information, but in the other case, the value maupum avail of the habit of reading books will fade as well as literature and valid source of its truth becomes a doubt. This is a daunting challenge for libraries to become a place that can provide brightness information and knowledge also should not miss from the rapid sophistication of information and technology.

In answering and facing various challenges and constraints that exist, there are several strategies according to flax and lina that can help minimize these constraints. Some strategies are:

\section{The Technology Strategy}

In daily reality we see that the demands of each visitor is increasing from year to year. Whether it demands in terms of speed of service, accuracy of data archiving books, interlibrary book lending breadth (cross serviceability). And also the limitations of manpower to serve all the demands of the visitors. To anticipate the HR needs to be improved and need to be equipped with sophisticated information technology. With the sophistication of information technology in this era of globalization will be able to answer all the demands of the patrons of the library who want excellent service. With the application of appropriate information technologies will 
increase library performance in all aspects, especially in the field of management. Thus would have posed a great satisfaction to the patrons of the library. And the library will be a place of learning both for the people. We can see the results of the following interview conducted by researchers at the UPT. Perspustakaan Agency, Archives and Documentation Bukit Batu subdistrict:

"The use of technology in UPT. This library is virtually non-existent. In terms of making a membership card for example, are shaped manually. Indeed, there is as much as a single computer, but in conditions that can not be used. For service information about material catalog library services shaped by a code number that is affixed to books on the bookshelf", (Interview with UPT and Reference Services Section, Bureau of Public Libraries, Archives and Documentation area of Bukit Batu subdistrict. 2016).

Based on interviews and documentation above we can know that technology is one important factor in the development of library services, field researchers noticed that the existence of the facilities and technology-based facilities for pre UPT. Library sub District Bukit Batu insufficient, the researchers did not see the technology in UPT. The library. With these conditions must be a constraint that the unavailability of adequate support facilities which is a requirement for the smooth administration of the service.

The use of computerization of administrative services Library, archives, and various documentation purposes are the main things that factor into archival libraries in providing services to visitors.

"In the meantime, reports and a variety of administrative purposes still made using a computerized, but not made directly at the office library, typedelsewhere.".(Interview with parts library staff UPT. Agency Public Library, Archives and Documentation of the Regional District of Bukit Batu. 2016).
Interviews conducted by the author above can be a picture of one of the efforts undertaken by the Unit. Library to parties who have authority over -particularly the budget, namely the Library, Archives and Documentation Bengkalis about the need for procurement of computers and other technologies that are needed in the smooth process of the Library Administration at Bukit Batu subdistrict.

\section{Innovation Strategy}

Innovation is a system of organizational activities that transform technology from idea to commercialization. Innovation refers to the renewal of a product, processes and new services.

Talk about innovation development and empowerment of the library can not be separated from the service (customer service, customer care /customer satisfaction, customer satisfaction /service Exelent,good service). Strategic effort to achieve it is linked to many things, such as whether sufficient quantity and quality of existing human resources, whether sufficient support facilities and adequate facilities, whether the public could reasonably felt the benefits of a library or library community and feel attachment. Does every program that is run each has continuity? research and scientific studies need to be done to get a role model so that each what do be appropriate for the community.

Innovation Library Library Development and Empowerment assessed preformance two problematics, the first one is like where innovation Library Development. In the thinking of many people, of course, a library room in which there are a lot of books, people greeted the officer came, served and visitors will find a book, read it or bring it home, so here is finished. Not many people know that the library has so much to do, much to do, much can be done either in the process of providing facilities and services to the partnership for customer satisfaction. Not only satisfy customers but also how the customer can come back again and bring 
ideas, clicking apply ideas, and ultimately bring more benefits not just books, information, and knowledge but softskills, entrepreneurial and ultimately bring change masysarakat.

\section{Development Innovation Library is divided into 3:}

1. Innovation Service: customer care = Customer satisfaction $=$ Service exelent.Creating a better service, satisfying and sustainable is to remember that the library should Costumize:

a. The facilities were adequate, up to date

b. user Officer, intraktif with visitors

c. Leisure: space, condition, situation.

Documentation of the results we can know that a collection of books on the shelves of library books, not neat and visible visitors spend a long time in looking for a book. This is certainly making visitors spend a long time in looking for a book to be obtained. Conditions such as these should be a serious response to the libraries in the library's vision is oriented to the satisfaction of the visitor.

a. A diverse collection: up to date, complete.

b. Meeting the needs of users are not just books, but the program continues.

To determine objectively, the author tried to interview one of the visitors about how where the opinion of visitors about the facilities and comfort of the library.

"Facilities we get when visiting them provided a reading room, a small room, but in the reading room there is a fan and the windows do not open so the room was hot and finally made the atmosphere uncomfortablereading.(Interview with one of the visitors UPT. Agency Public Library, Archives and Documentation of the Regional District of Mount Batu.2016).

Visitor response and documentation of the author above, we can know that one aspect of the library's main facilities reading room and forget not well facilitated. This is certainly one of the reasons less interesting your visitors to read a book in the library.
Comfort when reading is very important. This issue became a serious point for librarians that the existence of an improvement in the reading room of the library.

1. Innovation activities

should be made in participatory activities together with the user, must be inline between the activities of one another. And continuous further development and lead to the intellectual level of the society based on the public interest. The author tried to interview community leaders UPT village where the library is

"among the activities that never diupuyakan library districts on the momentum of the rock is the anniversary of Indonesia a few years ago. Namely held a contest to make a story about the origin of the District of Bukit stone, poetry and poetry contest, calligraphy contest and race speech. This activity is aimed at elementary school students and is held in the Library. However, the last 2 years there is no longer suchactivities." (Interview with Head Desa Bukit Batu subdistrict Sejangat Bengkalis. 2016)".

From interviews with one of the community leaders and some evidence of documentation of the above activities, we can know that this form of participatory community-based activities have been carried out by the intellectual level of the library. This would be an innovative step for the library closer position and role as an institution functioning in providing civic education in its territory.

2. Innovation Partnerships

will flourish if the library does not run itself, there must be a good partnership with the private sector as a sponsor or as cooperation with the program and an indicator of success is clear. The actions that have been done is socialization to schoolschool with a form of visits carried out by the library district. This was done with the forms of cooperation. To find out more investigators interviewed directly to one of the teachers at SMAN.1 Sei.Pakning. 
"Sekolahyang party partnership ever undertaken is an effort to encourage students to always visit kepustaka and read a book. This is done in the form of a briefing on the students when the library was asked to become the coach at a ceremony Monday at theschool."(Interview with a teacher SMAN1 Sei. Pakning 2016).

Researchers looked at the best management in the introduction of civic Library Library beginning of a partnership with a variety of school. With the actions taken by the head of the Unit with a visit to school-school environment of districts, certainly indirectly help socialize the District Library Unit to students.

\section{Empowerment Public Library}

Thinking about the vast area and the number of people who are on it, then we have to think how much we are able to serve them all. Obligatory to have to serve them because as entitlement society, and like where it can reach all of them.

Satellite service concept could be a form of participation of service, community contribution and kesinergian services, building public reading, libraries around the car to reduce the burden of service to the concept of shared go away apparatus related to the parish level. Regarding this, the authors interviewed librarians:

"to reach out to the rural library service that is distant from the location of the library, then the library districts provide one car unit called the bookmobile. Mobile library is accompanied by readingmaterial."(Interview with Section Reference Unit, Agency Public Library, Archives and Documentation of the Regional District of Bukit Batu. 2016)

From the information interview documentation of the above, we can know that the existence of the reforms in improving the facilities in order increase public interest. The mobile library in the form of a mobile unit is expected to reach the area of the villages are located far from the township library.

\section{Operations Strategy}

a. Bukit Batu subdistrict bookmobile bookmobile is part of the Public Library. The mobile library to provide the services extension, the communities are located far from the library. The mobile library provides its mobile services come in several settlements, and where terkosentrasinya number of people, such as schools, village office. The mobile library typically use a car designed specifically for the purpose of the library, to the islands or watershed is usually called a floating library.

The mobile library is a library that moves bring library materials such as books, to serve people from one place to another are not reached by the library service area evenly all, the public library should remain in the service of its existence to the public. The mobile library Bukit Batu subdistrict shaped mini bus, operating on Tuesdays, once a week. The village is often visited by a mobile library is a sub-district village gravel hill stone hill which is located very far from the library district. Mobile Library is working operations of the Agency for Libraries, Archives and Documentation Bengkalis.

"The mobile library operates for two districts, namely Bukit Batu sub-district and District Siak Kecil. On the day sealasa operationalized in UPT. Bukit Batu District Library and Thursday used untok operasionl right to UPT. Library SiakKecil."(Interview with staff operasionalmobil around UPT. Agency Public Library, Archives and Documentation of the Regional District of Bukit Batu. 2016).

From the description of the interviews conducted above we can know that the mobile library units are in operation, used in rotation by two UPT Library districts. This would make library operations less effective, due to the mobile library car units used by two UPT Library.

The mobile library service is essentially an open, democratic, because the mobile library serves all levels of society 
regardless of social status, cultural, economic, educational, trust mapun statuses sharing. Masyasrakat all citizens, regardless of age limits, free to use without a mobile library services. The mobile library service system conducted by the Library Unit Bukit Batu subdistrict, namely:

an open service(open access)

In this system the visitor can freely choose and find themselves existing library materials in the car. Direct visitors to the crust shelves of books and magazines and newspapers are available in the library around when visitors have difficulty in determining searchable library materials, they can ask the librarian.

Basically two service systems, namely open and closed, but to apply the system of services covered, should the need for the number of members of more than two people. It is also not possible because the size of the mini-bus is used not so great. Another advantage, which saves energy. In this system the officers did not need to take the desired book users, librarians just recorded and then fetch the books that have been read and the returned place that day.

Barriers faced On the UPT service. Agency Public Library, Archives and Documentation of the Regional District of Bukit Batu.

The following will explain the obstacles that occur On UPT service. Agency Public Library, Archives and Documentation Bukit Batu subdistrict, is as follows:

1. Number of borrowers of books, especially school children are still very young children namely elementary school (SD) equal and school junior high (JSS) equal cause many books not returned. This condition is due to low awareness of the borrowers of books in general are still children to return books on time.

Under theseconditions, the authors conducted interviews with the board of UPT. Agency Public Library, Archives and Documentation area of Bukit Batu subdistrict in order to seek out clarity on these issues, based on interviews conducted by the author, can be obtained the following explanation:

"one of the barriers of our employees in the process of the library is still the number of borrowers of books did not return a book keperpustakaan accordance with a predefined time. As a result, the more the number of existing collection of books in the library continues to wane, one reason is the lack of awareness of the borrower's books to return the books to suit their time, so the library does not need to add to the collection at anytime."(Interview with the Services Section and the Reference Unit, the Library general, Archives and Documentation of the Regional District of Bukit Batu. 2016)

Based on the results of interviews conducted by the author with the management of UPT. Agency Public Library, Archives and Documentation Regional Bukit Batu subdistrict it can be concluded that the lack of awareness of the borrower book to return the book to the library became the main cause that led to the books in the library of steadily decreasing.

2. The number of damaged books In addition to the problem books that are not returned, the number of damaged books like torn, folded and was often painted by the borrower as well as the missing books became a big problem also can not be avoided by UPT. Agency Public Library, Archives and Documentation of the Regional District of Bukit Batu. This is because these conditions will cause the number of books available in the library collection will also be reduced.

For more details about these problems, the authors conducted interviews with the board of UPT. Agency Public Library, archives and documentation Regions Bukit Batu subdistrict in order to find clarity on these issues, based on interviews conducted by the author, can be obtained the following explanation:

"in addition to the problem that so many borrowers who do not return books keperpustakaan, another issue that occurs is her still many students who do not want to 
take care of books borrowed. There were torn, folded, was often painted even the book was lost and did not returned. These conditions make the number of books the library collection will continue to decrease because the proper number of books available in the library is growing and notdeclining. "(Interview with Service Unit and Reference Unit. Agency Public Library, Archives and Documentation Bukit Batu subdistrict, 2016)

Based on the interview the writers do with Unit manager. Agency Public Library, Archives and Documentation Regional Bukit Batu subdistrict, we can conclude that many of her books are folded, in graffiti and ripped also the main cause of existing books in the library continues to decrease.

3. Many of the Borrower book Who Will not Follow Rules Applicable in the Library.

The number of borrowers of books that do not follow the rules imposed the libraries makes it difficult to apply the orderly administration of the library. One example is the implementation schedule tentag keperpustakaan book return at a specified time.

To find out more about these problems, the authors conducted interviews with the management of UPT. Agency Public Library, Archives and Documentation of the Regional District of Bukit Batu in order to find clarity on these issues, based on interviews conducted by the author, can be obtained the following explanation:

"actually we already enforce rules and policies of the concrete in order to implement efficiency administrative services in this library, just that we are still experiencing difficulties so today. One of the big problems that we face today is the lack of awareness among visitors and borrowers of books for adhering to the rules and policies that have been defined, such as fines and replace books hilamg, but we are very difficult because the number of visitors and borrowers enough books alot."(interview with Services Section and
Reference Unit. Agency Public Library, Archives and Documentation Bukit Batu subdistrict, 2016)

Based on the results of interviews conducted by the author with the management of UPT. Agency Public Library, Archives and Documentation Regional Bukit Batu subdistrict, we can conclude that his lower awareness among visitors and borrowers of books to obey the rules that have been imposed. efektifatas leads to efficiency and administrative services difficult to implement

4. Lack of Employees, Facilities and Infrastructure that Supports Smooth Administration.

In providing the services performed by the library is still not as expected as the management of borrowing and returning books, the employee in charge of only one person causes the queue in the management and the maintenance of interest ketata usahaan not use the computer. It is definitely faster terselesainya hamper service in the management of interest that occur in UPT. Agency Public Library, Archives and Documentation Bukit Batu subdistrict.

The steps undertaken to effective Administration.

In order to effective administration in UPT. Public Library, Archives and Documentation of the Regional District of Bukit Batu, then the UPT. Agency Public Library, Archives and Documentation Bukit Batu subdistrict Regional perform concrete steps to address some of the problems and obstacles faced. The steps undertaken UPT Agency Public Library, Archives and Documentation Bukit Batu subdistrict Region are as follows:

\section{Setting a Library Card Making Policy}

This effort was undertaken to find out who those who visit and borrow books there in the library. For visitors who are not willing to make a library card, the library is not willing to serve the process of borrowing books, so that the book can not be taken out of the library environment. 
For more details, the authors conducted interviews with the management of UPT. Agency Public Library, Archives and Documentation of the Regional District of Bukit Batu in order to seek out clarity on these issues, based on interviews conducted by the author, can be obtained the following explanation:

"One of the efforts made to implement the administrative services is to create a system of making cards library. So for visitors who are not willing to make a library card, then we will not serve if they are in gin borrow a book". (interview with the administrator of the Agency UPT Public Library, Archives and Documentation of the Regional District of Bukit Batu. 2016).

Based on the results of interviews conducted by the author with the management of UPT. Agency Public Library, Archives and Documentation Regional Bukit Batu subdistrict, we can conclude that the policy-making library card intended to impose administrative services in the Library. If not willing to undertake the manufacture of a library card, then the library is not willing to lend books available in the library.

\section{The system imposed a fine}

addition to disorderly conduct Adaministrasi, the library also introduced a system of fines for overdue books are returned and replace the damaged books.

To find out more about the development policy, the authors conducted interviews with the management of UPT. Agency Public Library, Archives and Documentation Regional sub-district of Bukit Batu in order to find out the clarity of the policy, based on interviews conducted by the author can be obtained the following explanation:

"in addition to imposing the manufacture of a library card, we also impose fines and policies to replace books lost or damaged. In this way we expect awareness of visitors and borrowers better books in the library "(interviewwith business UPT.Badan Public Library, Archives and
Documentation of the Regional District of Bukit Batu. 2016).

Based on the results of interviews conducted by the author with the management of UPT. Agency Public Library, Archives and Documentation Regional Bukit Batu subdistrict, we can conclude that other efforts undertaken by the library to effective administrative services is by imposing fines and replace damaged and lost books.

\section{3. do Periodic socialization}

These effortsto introduce the library to the general public and to visitors in particular. By doing a regular socialization with facilities and infrastructure in the form of an official car unit that is used as a mobile library that is run every Tuesday hoped that the community we really know our library deeper.

To find out more details about these policies, the authors conducted interviews with the management of UPT. Agency Public Library, Archives and Documentation of the Regional District of Bukit Batu in order to find out the clarity of the policy, based on interviews conducted by the author, can be obtained the following explanation:

"to introduce the library of this to the public, then we always socialize regularly with facilities and infrastructure in the form of a single unit of official cars used as a mobile library that is run every Tuesday, for the existence and existing policies diperpustakaan known to the wider community, so expect both the public and the visitors really get to know and understand the rules and regulations diperpustakaan "(interviewwith business UPT.Badan Public Library, Archives and Documentation of the Regional District of Bukit Batu. 2016).

Based on the results of interviews conducted by the author with the management of UPT. Agency Public Library, Archives and Documentation Regional Bukit Batu subdistrict, we can conclude that other efforts are made to introduce the library is to socialize regularly with facilities and 
infrastructure in the form of an official car unit that is used as a mobile library.

Of all the interviews conducted by the author can be concluded that the administrative proceedings due to lack of good infrastructure is inadequate in UPT. Agency Public Library, Archives and Documentation Bukit Batu subdistrict, so that administrative proceedings be slower and less effective. in the manufacture of a library card is still rent elsewhere or not be made at the library. we know that technology is one important factor in the development of library services. field researchers saw that the absence of the presence of facilities and technology-based facilities for pre UPT.

Library In providing services which do still not as expected as the maintenance of interest administration also not use the computer. It is definitely faster it almost accomplised service in the management of interest that occur in UPT. Agency Public Library, Archives and Documentation Bukit Batu subdistrict. With these conditions must be a constraint that the unavailability of adequate support facilities which is a requirement for the smooth administration of the service. The use of computerization of administrative services Library, archives, and various purposes of documentation are the main things that factor into archival libraries in providing services to visitors and lack of coordination of Perpustakaaan Public Archives and documentation Bengkalis to Public Library, Archives and Documentation Bukit Batu subdistrict these causes lack of funds Bukit Batu subdistrict's library in managing the library.

Furthermore, during the author conducted observations, the Library Unit level this district very quiet visitors. her low awareness among visitors and borrowers of books to obey the rules that have been imposed. and his many books are folded, in graffiti and major facilities the library reading room and forget not well facility
It would be one less reason as interested visitors to read a book in the library. Comfort when reading is very important. The shelves of library books, not neat and visible visitors spend a long time in looking for a book. Conditions such as these should be a serious response to the libraries in the library's vision is oriented to the satisfaction of the visitor.

The policy pursued to improve the management of the library a library card manufacturing policy intended to impose administrative services in the Library. If not willing to undertake the manufacture of a library card, then the library is not willing to lend books available in the library. other efforts undertaken by the library to effective administrative services is by imposing fines and replace damaged and lost books. The activities to introduce the public library we can know with any form of participatory community-based activities carried out by the intellectual level of the library. As the race made the scientific work for students This would be an innovative step for the library closer position and role as an institution functioning in providing civic education in its territory. And their car around to reach remote areas. of the library for the existence of the library can be known by the public. And conduct a library orientation for students, joint use library collection to other regions, increasing resources and honorary employees by conducting training library.dan library user education for library users.

\section{CONCLUSIONS}

Based on the results of research and discussion on the Strategy Unit. Agency Public Library, Archives and Documentation Bukit Batu subdistrict Bengkalis in Providing Services to the People it can be concluded as follows: (1) Some of the steps by steps in the Library to the public right to know, it could be quite good. It was said, because already the innovative measures, such as their 
partnership to the school, the bookmobile to reach remote areas and activities that have been done based on the intellectual level of the library. although not yet organized into a systematic development strategy. This is because the quantity and quality of human resources is not optimal in perannnya. (2) The obstacles in Faced UPT. Agency Public Library, Archives and Documentation Regional sub-district of Bukit Batu in effecting service are as follows: (a) Lack of number of employees, the need for education and training for employees and facilities that support the smooth administration of (b) Many borrowers of books that do not return books (c) Many books were damaged (d) Many borrowers of books that do not follow the rules imposed library.

\section{Recommendations}

Based on the analysis and research in the field of the srtategi UPT. Agency Public Library, Archives and Documentation Bukit Batu subdistrict Bengkalis in providing services to the People, the author tries to give advice as follows: (1) It is expected that the officer UPT Agency Public Library, Archives and Documentation affluent subdistrict of Bukit Batu can improve administrative services better, (2) It is expected that the obstacles that occur can be addressed and can be resolved properly. (3) It is expected that the measures put in place to run. The need for more targeted coordination and responsibility of the responsible party is the government Bengkalis in terms of completeness of facilities and infrastructure UPT Libraries in various districts.

\section{REFERENCES}

Barthos. 2000. Manajemen Kearsipan (untuk lembaga Negara, swasta dan perguruan Tinggi ). Jakarta: Bumi Aksara

Basuki, Sulistyo. 1993. Pengantar Ilmu perpustakaan. Jakarta: Universitas Terbuka Departemen pendidikan dan kebudayaan.
Bonder, Adir Ed. Desember 1999. Мепији Profesionalisme layanan perpustakaan dalam Perspektif layanan prima. Jakarta: perpustakaan nasional RI.

David, Fred. R. Terjemahan Paulyn Sulistio dan Harryadin Mahardika. 2006 Strategic Manajemen. Jakarta: Salemba Empat.

Karmidi Martoatmojo. 2002 . Pengelolaan Perpustakaan. Bandung: Alfabeta

Kuncoro, Mudrajad. 2005. Strategi "Bagaimana Meraih Keunggulan Kompetitif”. Jakarta: Erlangga.

LAN Republik Indonesia. 2006. Strategi Peningkatan Kualitas Pelayanan Publik. Jakarta: Penerbit LAN

Lena dan Lina. 2008. Manajemen Strategi operasi Teori dan riset di Indonesia. Bandung: Alfabeta

Moenir, HAS. 2002 Manajemen pelayanan umum di Indonesia. Jakarta : Bumi Aksara

Namawi, Hadari. 2005. Manajemen Strategik Organisasi non profit bidang pemerintahan. Yogyakarta : Gadjah Mada University Press

Nurhadi, Didi. 1999. Pengembangan Koleksi Referensi Perpustakaan. Jakarta: Penerbit Perpustakaan Nasional Indonesia

Purwanto, Iwan. 2008. Manajemen Strategi. Bandung: CV. Yrama Widya.

Sinambela. 2006. Reformasi Pelayanan Publik. Jakarta : Bumi Aksara

Solihin. 2001. Otonomi Penyelenggaraan Pemerintah Daerah. Jakarta: PT. Gramedia Pustaka Utama

Sudarsono, Blasius. 2006. Antologi Kepustakawanan Indonesia. Jakarta: Penerbit Sagung Seto

Sugiarto. 1999. Pelayanan prima. Jakarta : PT. Gramedia Indonesia

Sugiyono. 2003. Metode Penelitian Adminstrasi. Jakarta: Alfabeta

Sulistio. 1994. Pengantar Ilmu perpustakaan. Jakarta: Universitas Terbuka Sumardi. 1998. Pengelolaan perpustakaan di Indonesia. Bandung: FKIP Bandung 
Sutarno, N.S. 2005. Tanggung jawab perpustakaan. Jakarta: Penerbit Panta Rei Tjiptono, Fandy. 1996. Manajemen jasa. Yogyakarta: Penerbit Andi Offset

Wendel, Laura. 2000. Perpustakaan Untuk Kita Semua. Jakarta: Penerbit Coca Cola Foundation

Yahyo, Y. 2001. Layanan perpustakaan dan Informasi. Jakarta: Depdiknas

Keputusan Menteri pendayagunaan Aparatur Negara Nomor 63/ KEP/ M.PAN/ 2003. Tentang: Pedoman Umum Penyelenggaraan Pelayanan.
Peraturan Daerah Kabupaten Bengkalis Nomor 10 Tahun 2008. Tentang: Susunan organisasi dan Tata Kerja UPT. Badan Perpustakaan Umum, Arsip dan Dokumentasi Kecamatan Bukit Batu. 